\section{THE NEW AUSTRALIAN MUD-FISH}

I $\mathrm{N}$ his well-known essay upon the arrangement of the extinct fishes of the Devonian epoch, published in the Memoirs of the Geological Survey* Professor Huxley, after showing that the Polypterus of the African rivers is probably the descendant of the Crossopterygian Ganoids with rhomboidal scales, continues as follows :- -

"It is singular that while the line of the rhombiferous Crossopterygida has so distinct a modern representative, the cycliferous Crossopterygida seem to have died and left no issue at the end of the Tertiary epoch. But, without wishing to lay too much stress upon the fact, I may draw attention to the many and singular relations which obtain between that wonderful and apparently isolated fish, Lepidosiren, sole member of its order, and the cycloid glyptodipterine, ctenodipterine, phaneropleurine, and coelacanth Crossopterygida. Lepidosirent is in fact the only existing fish whose pectoral and ventral members have a structure analogous to that of the acutely lobate paired fins of Holoptychizus, of Dipterus, or of Phaneropleuron, though the fin-rays and surfacescales are still less developed in the modern than in the ancient fish. The endoskeleton of Lepidosiren, again, is as nearly as possible in the same condition as that of Phaneropleuron, and is more nearly similar to the skeleton of the Cœlacanths than that of any other recent thus to connect what, in the opinion of some naturalists, are two very widely separated forms of the order Pisces. Since the announcement of this discovery appeared, a paper has been read before the Zoological Society of London, containing a preliminary account of this wonderful fish, by $\mathrm{Mr}$. Gerard Krefft, the curator and secretary of the Australian Museum, Sydney. Mr. Krefft proposes to call it Ceratodus forsteri, "after the Hon. William Forster, M.C.A., its discoverer."

The general form of Ceratodus forsteri, and its striking resemblance to Lepidosiren, will be at once seen by the accompanying figure, which has been reduced from one of the photographs forwarded to England by Mr. Krefft. The length of the specimen described (which, at the time the paper was written, was the only individual yet obtained) was about three feet ; it has a broad flat head, small eyes, and four limbs in the shape of flappers. The body is stated to be covered with large cycloid scales, ten rows on each side. A large gill-opening in front of the pectoral limb contains well developed branchiæ, but their accurate examination was not possible, on account of the bad condition of the specimen. A rather large pair of nostrils, situated just below the upper lip, communicates by a short tube with the roof of the mouth.

The skeleton of this fish is partly ossified and partly cartilaginous, the vertebræ being pure cartilage, and the ribs hollow tubes, filled with cartilaginous substance. The palate and upper part of the skull are bony, and the

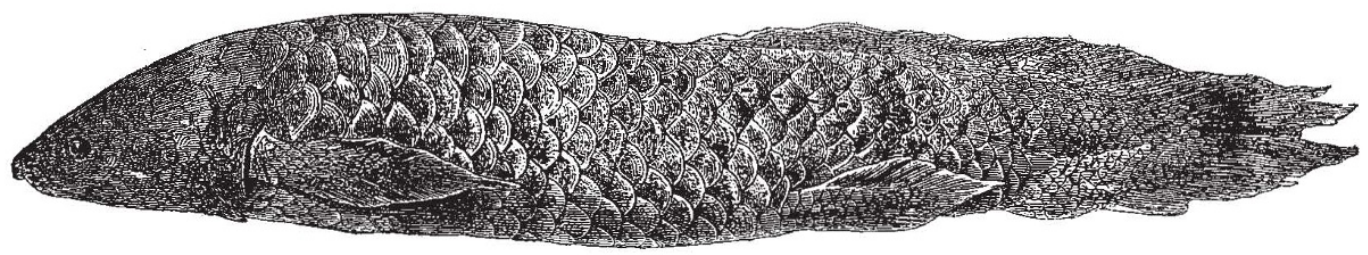

CERATODUS FORSTERT, THE NEW AUSTRALIAN MUD-FISH

fish; while perhaps it is not stretching the search for analogies too far to discover in the stiff-walled lungs of Lepidosiren, a structure more nearly representing the ossified air bladder of the Cœlacanths than any with which we are at present acquainted, among recent or fossil fishes. Furthermore, Lepidosiren is the only fish whose teeth are comparable in form and arrangement to those of Dipterus. Though Lepidosiren may not be included among the Crossopterygidæe, nor even in the order of the Ganoids, the relations just pointed out are not the less distinct: and perhaps they gain in interest when we reflect that while Polypterus, the modern representative of the rhombiferous Crossopterygidæ, is that fish which has the most completely lung-like of all air-bladders; Lepidosiren, which has been just shown to be, if not the modern representative of the cycliferous Crossopterygida yet their 'next of kin', is the only fish which is provided with true lungs. These are unquestionable facts. I leave their bearing upon the great problems of zoological theory to be developed by every one for himself."

In this remarkable passage, written some ten years ago, we may almost say that Prof. Huxley prophesied the discovery, announced in these columns some weeks since, $f$ of the new Australian Mud-Fish, which appears to unite the dentition and other peculiarities of some of the extinct Crossopterygians with the external form of Lepidosiren, and

$$
\text { * Decade x., } 286 x \text {. }
$$

† Sec Nature, No. 28 , Vol. ii. p. 38 . head is covered by two large scales. The tongue is very small, and is attached to what appears to be a large hyoid bone, ossified externally. The rays which support the dorsal and caudal fin consist of hollow tubes filled by cartilage. In the upper jaw are two large teeth, which $\mathrm{Mr}$. Krefft terms incisors, and which are obviously the representatives of the peculiar teeth in the corresponding position in Lepidosiren.* Behind these are dental plates, divided on each side into six tooth-like projections. The l wer jaw is provided with similar dental plates, but has no teeth in front; the rami are joined only by a tough skin.

Such is an abstract of Mr. Krefft's preliminary notice of this strange animal, which is certainly one of the most remarkable zoological novelties that Australia (that land of wonders) has yet produced. It is singular, indeed, that a creature like this, which appears to have been long well known to the squatters of Queensland, should have hitherto altogether escaped the observation of naturalists. It is said to have flesh of the colour of salmon, and to be excellent eating, so that the settlers have named it the "Burnett," or "Dawson salmon," from the two Queensland rivers in which it is principally found. The native name is given by Mr. Krefft as Baramoonda or Baramoondi. The fish is stated to attain sometimes a length of six feet and upwards.

* See Dr. Cobbold's discussion of these teeth, in his article on the cranium of Lesidosiren: Proc. Z.S., 1862, p. x29. 
As regards the correct position of the Ceratodus forsteri in the "Systema Naturæ," we must, of course, wait until more specimens are procured for the examination of competent naturalists, the single example in the Australian museum being in an incomplete condition, from the internal organs having been removed. Mr. Krefft calls it a "gigantic amphibian," not being aware probably that all the best authorities now follow Johann Müller in classing Lepidosiren as a fish. It is, however, certain that, as Dr. Günther pointed out at the meeting of the Zoological Society when Mr. Krefft's paper was read, this fish must either be placed, along with Lspidosiren and its African representative Protopterus, in the order Dipnoi, or that it must form of itself a new division of the Ganoid fishes. We must know more of its internal structure, and in particular of the organs of circulation, before this question can be decided. Mr. Krefft has referred the fish to the genus Ceratodus, a name established by Agassiz in his " Poissons Fossiles" for the indication of certain teeth which were then supposed to be those of some kind of shark. Dr. Günther, our best living authority on the class of fishes, is, I believe, of opinion that, so far as the structure of Ceratodus is known, there is nothing to show that $\mathrm{Mr}$. Krefft's decision is wrong, though it would appear to me to have been better to have proposed a new generic name for this animal.

In conclusion, I may express a hope that this short notice may have the effect of calling the attention of some of the colonists of Queensland to the wonderful nature of this relic of the Devonian epoch that is now swimming about beneath their noses, and that they will cease, for the present at least, to kill it and eat it as "salmon." Any specimens that may "rise to their fly" should be carefully kept out of the way of the cook, preserved in alcohol and transmitted to the British Museum or some other scientific institution. When the existence of Ceratodus forsteri becomes more widely known, there will be no lack of applicants for examples of it.

P. L. SClATER

\section{NOTES}

THE Syndicate appointed by the University of Cambridge to consider the question of the manner in which provision may be made for the establishment of a Professorship of Physical Science, and increasing the facilities for instruction in it, have again reported to the Senate. It may be remembered that the former report, after having been discussed in the Schools, was referred back to the Syndicate by the Council. The present report, however, only differs in one important point from the former, in recommending that the increase in the tax levied upon the M.A. members of the University should be temporary instead of permanent. It had been hoped by many that the Syndicate would have taken courage from the general tone of the debate, have cancelled their former report, and proposed some bolder and more thorough measure. It is, however, not very probable that the University will accept the report. Several influential members of the Syndicate have not signed it; and there appears to be a growing feeling in Cambridge that, notwithstanding the obvious evil of delay, to postpone for a few months the appointment of a Professor would be better than to carry at once a temporary and unsatisfactory scheme.

THE Council of the Society of Arts at their meeting on Monday last, awarded the Albert gold medal for the present year, to M. F. de Lesseps, " for services rendered to arts, manufactures, and commerce, by the realisation of the Suez Canal."

WE regret to learn that Baron Liebig continues dangerously i1l. He has recently submitted to two operations for a very painful abscess in the shoulder, and continues very weak, but perfectly clear and cheerful, although believing that death is near.
THE new lectures on physiology at Trinity College, Cambridge, by Prof. Foster, will, we understand, be open to all members of the University, so that this liberal act on the part of the college is practically equivalent to the foundation of a professorship of physiology in the University.

There will be an examination at St. Peter's College, Cam. bridge, on Tuesday, June I4, for a Natural Science Scholarship, of the value of $60 \%$. per annum. It will be open to all persons who may desire to enter at the University. The subjects are chemistry, comparative anatomy, physiology, and botany. Names of candidates must be sent a week previously to Rev. J. Porter, tutor of the college, from whom further information may be obtained.

AT the meeting of the French Academy of Sciences, held on the zoth ult., Mr. Joule was elected a correspondent in the Physical section by 32 votes out of 43 . Of the remainder, Professor Lloyd obtained eight, and Professors Angström, Dove, and Volpicelli one each.

THE Senate of the Queen's University in Ireland has unanimously passed a resolution conferring the honorary degree of Doctor in Science on Prof. William King, in recognition of his scientific attainments.

$\mathrm{W}^{\dagger} \mathrm{E}$ learn from the Moniteur Scientifique, that M. R. Radau has been charged with a commission from the French Minister of Instruction to visit Germany, for the purpose of studying the organisation for instruction in the higher mathematics in the principal universities of that country, and prepare a report.

A MonumenT to John Kepler, at Weil der Stadt, the birthplace of the great astronomer, will be uncovered on the $24^{\text {th }}$ inst. Subscriptions have been received from all parts of Germany, France, Russia, and even North America.

ON Friday, May 26, Dr. Carpenter delivered a lecture on the Physical and Biological Conditions of the Deep Sea, in the Senate House, Cambridge. His remarkably lucid and interesting account of the results of the late expeditions, illustrated by some beautiful diagrams, was listened to with great attention by a very large audience, and at the conclusion, the Master of Christ's College (who occupied the chair in the unavoidable absence of the Vice-Chancellor) proposed, and Prof. Sedgwick seconded, a vote of thanks to the lecturer, which was carried with enthusiasm. The latter made some remarks upon the bearing of Dr. Carpenter's discoveries upon Geology, which showed that notwithstanding the burden of eighty-five years, the old fire was still burning brightly.

DR. HASSKARL, formerly superintendent of the Botanic Gardens, and introducer of the Cinchona plant into Java, pub. lishes a monograph of the Indian Commelinacea, especially those of the Indian Archipelago, with a few other species.

WE have received papers of Port Louis, Mauritius, for April 9 th, containing a report of the meeting of the Meteorological Society, held March 24, when a valuable paper was read "On the Origin of Storms in the Bay of Bengal," by the secretary, Mr. C. Meldrum, with special reference to the monsoons and cyclones of the Indian Ocean.

THE last volume of the "Transactions of the Linnean Society," just published, contains Mr. Carruthers's long-expected paper "On Fossil Cycadean Stems from the Secondary Rocks of Britain."

Mr. Charles T. Brown, of the Geological Survey of Demerara, has lately returned from a journey of three months' duration in the interior. He has examined the Potaro, Siparunie, and Burroburro rivers, and the country beyond the heads of the latter two, which he finds to be table-land, composed of slightly-inclined beds of sandstone and conglomerate. On the Potaro river he met with a magnificent fall, hitherto unknown. 